УДК 631.48:631.445.8(477.8)

\title{
FEATURES OF ONTOGENESIS AND GEOGRAPHY OF RENDZIC LEPTOSOLS IN THE WESTERN UKRAINIAN REGION
}

\author{
Andriy Kyrylchuk \\ Ivan Franko National University of Lviv, \\ P. Doroshenko St., 41, UA - 79007 Lviv, Ukraine, \\ e-mail: andriy.kyrylchuk@lnu.edu.ua
}

The article deals with theoretical and methodological principals of process-genetic approach concerning the study of ontogenesis and geography of soils at the regional level. Methods of geographical and genetic investigation of ontogenesis and geography of Rendzic Leptosols have been improved through the introduction of modelling techniques, soil chronological rows, and balance of substances and energy capacity evaluation of soil formation. Peculiarities of Rendzic Leptosols ontogenesis in natural and natural-anthropogenic landscapes with different biolithogenic conditions of soil formation have been established. Based on current investigations, schematic map of geography of rendzinas in Western Region of Ukraine has been made up. Particular approaches have been justified according to distinguishing such stages of ontogenesis of Rendzic Leptosols as: initial (primary) $\rightarrow$ perfect (development and improvement) $\rightarrow$ permanent (maturity and stability) $\rightarrow$ and evolution (self-development and quality changes). Chronological periodization of soilgeographic investigations of rendzinas in Western region has been achieved with periodization scheme of these studies made up. The analysis of energetic and thermodynamic properties of chronological rows of soil forming rocks and Rendzic Leptosols of Western region of Ukraine on different stages of their ontogenesis has been carried out. Parameters and indicators of elementary soil processes at different stages of rendzinas ontogenesis have been established. Formation peculiarities of morphological, physical, physical-chemical, and chemical properties of rendzinas on different stages of their ontogenesis have been shown. Consequently, characteristic features of rendzinas agrogenic transformation and scientifically based approaches towards usage and protection optimization of the investigated soils have been determined. Systematized and generalized pedochronologic information can be used to solve process-genetic, functional-geographical and classification-diagnostic problems, and tasks of rational application and protection of Rendzic Leptosols of Western Region of Ukraine. Suggested results of the research can be applied towards bonitet soil evaluation as well as monetary estimation of the land, and the development of territory organization projects, aiming at optimizing the soil-ecological condition of agricultural land. Obtained results are recommended for improving methods of soil-geographic and soil-agricultural zoning.

Key words: ontogenesis and geography of Rendzic Leptosols, elementary soil processes, stages of ontogenesis, agrogenic transformation.

(C) Kyrylchuk A., 2017 
The evolutionary-chronological problems of geographic-genetic or evolutionary soil science become more and more relevant nowadays. This is because the progress in understanding the general theoretical patterns of soils formation depends on their solution at the present stage of science development, and in practical terms, successful implementation of environmentally sound programs for rational use, reproduction and management of the soil resources.

In the history of geographic and genetic soil science, various aspects of the stage of ontogenetic soil development have repeatedly attracted attention of researchers and have been highlighted in the scientific works of Rode, Dushufor, Kovda, Dobrovolsky and others $[1 ; 2 ; 5 ; 16]$.

However, at present, there is a shortage of specific pedochronologic information and associated with it insufficient development or contradiction of many theoretical and methodological provisions in the field of ontogenesis and soil evolution. In particular, of great importance is comprehensive in-depth study of the essence, nature and rate of manifestation of individual elemental soils processes in the formation of the entire genetic profile, the ratio of tempos, direction and intensity of soil formation in a variety of bioclimatic, lithological and geomorphological conditions.

In this connection, there is a need to study the problem of soils ontogenesis, for example, Rendzic Leptosols, that is, the identification of the essence of elemental soil processes at different stages of formation and development of their genetic profile. The peculiarities of their functioning and spatial differentiation, which require special purposeful studies of pedophilia phenomena, which cover various physical and geographical conditions and individual genetic types of soils are of great importance. Complex pedochronologic and geographic studies of Rendzic Leptosols in Western region of Ukraine were not conducted. Therefore, the obtained results of ontogenesis features and regularities of the geography of Rendzic Leptosols in the region are actual.

The present stage of the development of genetic-geographical research is characterized by the presence of two opposite tendencies. On the one hand, the number of specific works devoted to the issues of genesis and the geography of modern soil decreases, and on the other hand, some progress is observed in global soil science, and in "depth" of soil studies as a modern pedosphere. The rejection of the direct actualism in relation to the genesis and geography of soils, allows us to formulate more adequate notions of complex combinations in the soils of different age generations signs, inherited from parent rocks, from different stages of ontogenesis and soil evolution, as well as from modern periods of soils life.

Today, the theoretical and methodological basis of evolutionary, evolutionary-genetic and historical soil science is represented in scientific works of Dushufor, Kovda, Targul'yan, Abakumov, Lisetskiy, Gogolev, Vernander, Poznyak, Kyrylchuk and others $[1 ; 2 ; 5 ; 6-9$; 14-17].

The present stage of the development of theoretical soil science is marked by an increased interest in two fundamental concepts, basic in geographic and genetic approaches to soils. Based on the extended theoretical and methodological understanding of functioning, formation and evolution of soil systems, the "New-Dokuchaev triad" of soil formation is complemented 
by another structural link, the processes of multiphase soil system functioning. Thus, the medium structural link of the triads - "processes" - is divided into the processes of system functioning and the process of formation, accumulation and differentiation of solid phase products in the soils, that is, divided on Elementary Soil Processes (ESP). Such a unified formula of soil formation becomes a tetrad: Factors $\rightarrow$ Functioning processes $\rightarrow$ ESP $\rightarrow$ Properties of Soils.

The genetic knowledge of the soil include: 1) identifying the set, combination and intensity of the main ESP that formed the given soil; 2) identifying the sequence of changes in the properties of soils and ESP that form them in time, that is, the introduction of changes in the set, the combination and intensity of the ESP in the period from the zero-moment soil formation to the moment of the soil study. Consequently, at the present stage of soil science development, the factors of soil formation do not have such decisive importance in creating specific soil properties that they were given earlier. They are determined by numerous individual phenomena or micro processes, more precisely, by dynamic changes of the four soil phases in time.

So, the nature of soil formation should be considered by the changes in the soil itself, conditioned by the specifics of the regimes and the ESP, but not by the interaction of factors. Based on the generalization and synthesis of the two concepts and the recognition of the dominant role of elementary soil processes in the genetic knowledge of the soil, Targulian (1982) proposed a phenomenological definition of soil ontogenesis. Ontogenesis is the identification of the soil-forming processes essence at different stages of the soil genetic profile formation, from its origin on an initial parent rock to a relatively mature state of "dynamic maturity".

Despite the considerable number of scientific works in the field of evolutionary soil science, the main points of the theoretical and terminological foundations of this scientific approach remain controversial or insufficiently substantiated. Among them, one of the leading places takes the problem of "self-development and soil evolution".

We consider that the development of soils (or soil ontogenesis) is an irreversible qualitative change in soils that is associated with the change in their intrinsic properties and composition, and hence external connections and functions. At the same time, the evolution of soils is their change in time in the process of factors interaction in soil formation, aimed at achieving an equilibrium state with the existing physical and geographical situation (climate, rocks).

In the process of ontogenesis, the soil can: 1) reach the climatic state, but in the future its development stops; 2) develop infinitely long, since the ontogenesis process is infinite and continues until the state of independent soil-forming factors remain stationary [2].

The studies conducted by many scientists have established that the evolution of the soil at different stages occurs at different speeds, and each stage of ontogenesis is divided into two phases. First, the phase of formation, that is, the phase of relatively rapid changes in the properties of soils, and second, the phase of climax, that is, the phase of the relatively equilibrium state with the environment, which is characterized by slow changes in the soil and a certain combination of elemental soil processes (ESP). 
Based on the analysis and generalization of thematic literary sources and our own longterm research, we consider that the concept of successive stages of ontogenesis of soils needs to be clarified today. In particular, we propose to call, the primary stage, an initial stage $\rightarrow$ stage of development - a perfect stage (stage of improvement) $\rightarrow$ stage of equilibrium functioning or climax - a permanent stage (stable, sustainable) $\rightarrow$ and additionally highlight the evolutionary stage (qualitative irreversible changes of the invariant). We hope that this approach will lead to a certain rethinking of the theoretical and methodological treatment of ontogenetic stage of soils, and improving the theoretical and terminological apparatus for the Soil Science [12].

According to the International Union of Soil Sciences Working Group WRB (2007), the soil is classified as Rendzic Leptosols developed on the products of weathering limestone and marls. Soil profiles are thin, developed on weathered parent rock enclosing approximately $45 \%$ of gravel and stones. Soils have continuous hard rock within $25 \mathrm{~cm}$ from the soil surface. Topsoil is represented by Mollic horizon with a thickness between 10 and $25 \mathrm{~cm}$ directly overlying material with a calcium carbonate equivalent of more than $40 \%$ (percent), or less than $10 \%$ (percent) (by weight) of fine earth from the soil surface down to a depth of $75 \mathrm{~cm} \mathrm{[3;4].}$

Taking into account soil classifications Turf-carbonate soils (Ukraine, 1977), Petrozems and Litozems (Russian Federation, 2004), Rendzic Leptosols (WRB, 2012) are considered to be the analogues of Rendzinas $[3 ; 4 ; 17]$.

We live in a World of soil, the total number of which is about 300 species, among which Rendzinas occupy one of the main places. The area of World Rendzic Leptosols is 17 million $\mathrm{km}^{2}$ (FAO, WRB), or 12,9\% of the world's land. Significant amounts of Rendzinas are observed in countries of Central and Eastern Europe, North America, Australia, the Baltic States, the Russian Federation, Belarus, and Moldova [4].

Ukraine occupies a leading place among the Central-Eastern European countries, the territories of which are rich in Rendzinas (or Rendzic Leptosols). Rendzic Leptosols and Carbonate Chernozems occupy more than $12000 \mathrm{~km}^{2}$ in Ukraine, which is $2,2 \%$ of the Ukrainian areas of arable land. In Western region of Ukraine both Rendzinas and Carbonate Chernozems, formed on eluvium carbonate parent rocks, occupy the area of $1622 \mathrm{~km}^{2}$ or $13,5 \%$ of corresponding soils area in Ukraine, $83,2 \%$ are arable lands.

The territory of Western Ukraine administratively divided into eight regions: Volyn', Rivne, L'viv, Ternopol', Khmelnitsky, Ivano-Frankivsk, Chernivtsi and Trans Carpathian (Fig. 1). The total area is $128900 \mathrm{~km}^{2}$ that makes $21,4 \%$ of the total area of Ukraine. Considerable extension of Western Ukrainian territory from north to south and from east to west favored the formation of natural conditions peculiarities and their spatial differentiation. According to physic-geographic scheme of Ukraine regionalization, the given territory is allocated within such azonic regional landscape units, as the territory of Polisya, Western Ukrainian territory and Ukrainian Carpathians $[6 ; 11 ; 13]$.

Natural factors with spatial heterogeneity and contrast range caused by geographic position, geological structure, geomorphologic and bioclimatic peculiarities play an important role in soil cover functioning, intensive development of soil processes and regimes, formation of soil properties and conditions of their usage. In different regional landscapes, different factors are predominating in soil forming processes. In Polisya territory, the most sufficient 


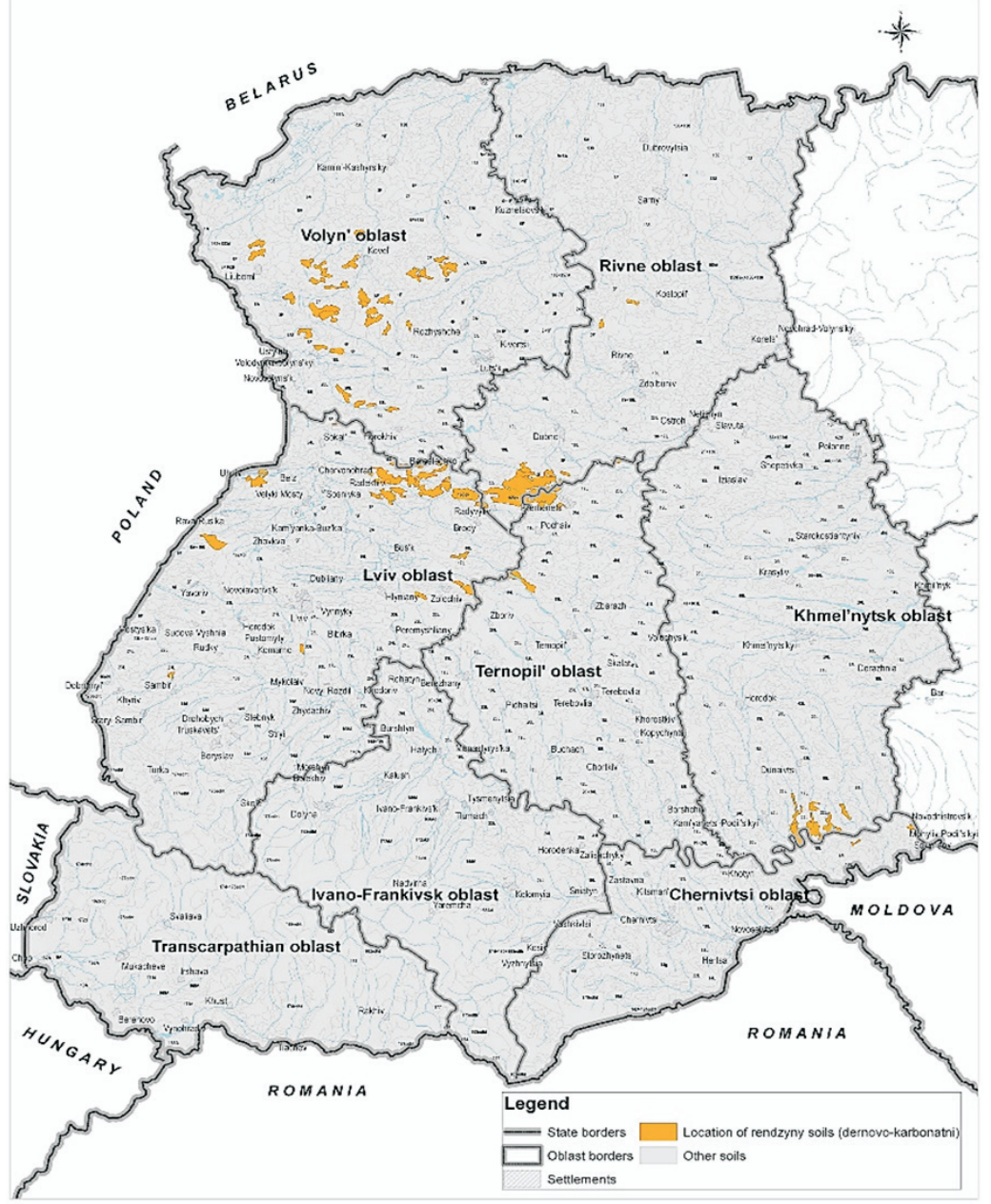

Scale 1: 1500000

Fig.1. Map of administrative districts and Rendzic Leptosols (Rendzinas) distribution in Western region of Ukraine (Source: Author's map)

Рис. 1. Карта адміністративних областей та поширення Rendzic Leptosols (рендзин) Західного регіону України (Джерело: авторська карта).

soil formation factors are parent rock lithology, vegetation, and surface and soil humidification conditions. In Western Ukrainian territory, with uniform less loam cover, the soil formation is influenced, primarily, by climatic peculiarities and vegetation, and the relief, as the major factor of different level of erosion processes display. In Ukrainian Carpathians, the character and direction of soil forming macro-process are largely caused by absolute altitude, relief, slope exposition and the character of soil parent rocks.

Rendzic Leptosols (or Rendzinas) of Western Ukrainian region are intrazonal biolithological soils, formed in periodically wash and wash type water regimes, mainly under 
mixed and broad-leaved forests canopy with well-developed herbaceous cover on eluviumdiluvium products of chalk, cretaceous marl, marl, and Upper Baden limestone weathering [9].

The highest $\mathrm{CaCO}_{3}$ content is present in the products of eluviogenesis of chalk, which makes from 75 to $98 \%$. $\mathrm{CaCO}_{3}$ content in the products of eluviogenesis of chalk marl is also quite high, ranging from 40 to $95 \%$. Somewhat lower $\mathrm{CaCO}_{3}$ content presented in the products of eluviogenesis of cluster, chemogenic and lithothamnium limestones, in which it varies from 54 to $92 \%$.

Rendzinas formation on the products of eluviogenesis of carbonate parent rocks causes significant $\mathrm{CaCO}_{3}$ content in the soil profile. Almost all investigated soils are medium and strongly carbonate on the surface and within the profile.

A characteristic feature of Rendzinas is the presence of eluvium of original parent rock as fragments of various size and shape in the profile, as well as finely dispersed carbonate material, which is not morphologically identified in the solid phase.

The basis of Rendzinas evolution is a gradual leaching of $\mathrm{CaCO}_{3}$ rocks. According to many investigations, such characteristic features of carbonate leaching process from soil have been highlighted: 1) reducing of quantity and the size of initial carbonate rock fragments and carbonation of solid phase in the upper horizons; 2) corrosion of carbonate particles surface; 3) appearance of yellow-brown iron hydroxide covering on the surface of carbonate particles; 4) decreasing of fragments strength in carbonate rocks; 5) appearance of silicate particles carbonate crusts and covering on the bezel surface, which were formed due to precipitation of secondary carbonates from $\mathrm{Ca}\left(\mathrm{HCO}_{3}\right)_{2}$ solution by evaporation of the latter; 6) appearance of terrigenous material dusting powder on the surface of carbonate broken stone [8-10].

In the classification, the stages of this process define the subtypes of Rendzinas, where one of the main diagnostic features is the presence of morphologically expressed or unexpressed carbonate accumulations, in some form or other, at a certain depth, which is detected by $10 \%$ hydrochloric acid $(\mathrm{HCl})$. Typical Rendzinas react on the surface under the influence of $10 \%$ hydrochloric acid, leached only at the bottom of the profile, ashed (according to new terminology lessivage), have signs of colloids redistribution in the profile and react only within the parent rock.

In Western Ukrainian region, the most widespread Rendzinas subtypes: 1) typical Rendzinas with underdeveloped (weakly-developed $<25 \mathrm{~cm}$ ) type of structure profile (the formula of the genetic profile: Ad (O) - Aca - Cca);2) typical Rendzinas with underdeveloped (short-profile from 25 to $45 \mathrm{~cm}$ ) type of structure profile (the formula of the genetic profile: $\mathrm{Ad}(\mathrm{O})-\mathrm{A} / \mathrm{Cca}-\mathrm{Cca}$ ); 3 ) typical Rendzinas with normal (modal) (fully profiled $>45 \mathrm{~cm}$ ) type of structure profile (the formula of the genetic profile: $\mathrm{Ad}(\mathrm{O})-\mathrm{ACca}-\mathrm{A} / \mathrm{Cca}-\mathrm{Cca})[7 ; 11 ; 17]$.

Designation of genetic horizons of investigated Rendzinas is given according to WRB (2007). Weak washed off and average washed off Rendzinas occupy fewer areas. Podzolic Rendzinas were not found.

The study of ontogeny of Rendzic Leptosols is to identify the nature and direction of elemental soil processes at different stages of the formation and development of their genetic profile - from its origin to the unchanged breed to a relatively mature state, that is, the achievement of "dynamic maturity", and an effective method of knowledge. The essence of these processes is a simulation method. This approach is based on the study of partial and 
general soil processes that are ergodic, since their stages in time may have analogues in space.

It has been established that composition, properties of Rendzinas and profiling processes in similar bioclimatic conditions depend largely on the lithological composition of soilforming rocks. Investigations of spatial-temporal models of Rendzinas of the Western region of Ukraine, which, according to the capacity of the profile, are divided into underdeveloped $(<25 \mathrm{~cm}$ ), short-profile (from 25 to $45 \mathrm{~cm}$ ) and fully-profiled $(>45 \mathrm{~cm}$ ) and confined to different elements of relief, types of groundwater rocks and vegetation were carried out using the method of chrono series. On the initial units of chronological series, products of eluviogenesis of dense carbonate rocks were taken, which at the time of research the soil formation process was unchanged (unchanged rock). As final units of soil chronological series, full-profile Rendzinas of denudation and flat-wavy plains were studied that reflect the maximum level of maturity of the soil in this region within the most autonomous positions [9].

The research revealed that ontogenetic reproduction of Rendzic Leptosols occurs under the influence of biogenic-accumulative and eluvial processes of soil formation, among which the bedding formation, the turf process, humus formation and humus-accumulation, as well as de-carbonation, decalcification and polymerization, play a decisive role. At the same time, the anthropogenic and pedo-turbational processes are the dominant processes of soil formation in anthropogenically impacted remains of artificially created terraced complexes.

The total area of Rendzic Leptosols in Western region of Ukraine, calculated according to large-scale soil investigations data in different years, makes $1019 \mathrm{~km}^{2}, 810 \mathrm{~km}^{2}$ of which are arable lands. Ploughed land is 79,5\% (Tab. 1) [11].

The overall Rendzic Leptosols area of Western Ukraine was calculated based on digitized Soil Map of Western Ukraine with 1:200 000 scale and ArcGIS 9 programme is $1466 \mathrm{~km}^{2}$. Different areas size was determined by their specification during further corrections of soil investigations. Using software ArcGIS 9, we have found that there are about 80 continuous Rendzic Leptosols outlines in Western Ukraine. The area of the biggest is $315 \mathrm{~km}^{2}$, the smallest is $2 \mathrm{~km}^{2}$. The average area of Rendzic Leptosols is $18 \mathrm{~km}^{2}$.

Table 1

The areas of Rendzinas (Rendzic Leptosols) in Western Ukrainian region, $\mathrm{km}^{2}$

(The numerator - total, denominator - arable lands)

Площі рендзин Західного регіону України, км² (у чисельнику - всього, знаменнику - рілля)

\begin{tabular}{|c|c|c|c|c|c|c|c|c|}
\hline \multirow[b]{2}{*}{ Types Soil } & \multicolumn{6}{|c|}{ Administrative districts } & \multirow[b]{2}{*}{ Total } & \multirow{2}{*}{$\underset{\%}{\text { Ploughed }}$} \\
\hline & Volyn’ & Rivne & L'viv & Ternopol' & Khmelnitsky & Chernivtsi & & \\
\hline $\begin{array}{l}\text { Rendzinas on } \\
\text { eluvium carbonate } \\
\text { soil-forming rock }\end{array}$ & $\frac{415}{359}$ & $\frac{231}{189}$ & $\frac{227}{192}$ & $\frac{27}{24}$ & $\frac{36}{2}$ & $\frac{83}{44}$ & $\frac{1019}{810}$ & 79,5 \\
\hline $\begin{array}{l}\text { Carbonate } \\
\text { Chernozems on } \\
\text { eluvium carbonate } \\
\text { soil-forming rock }\end{array}$ & - & $\frac{111}{107}$ & $\frac{312}{296}$ & $\frac{118}{79}$ & $\frac{62}{58}$ & - & $\frac{603}{540}$ & 89,6 \\
\hline$\sum$ & $\frac{415}{359}$ & $\frac{342}{296}$ & $\frac{539}{488}$ & $\frac{145}{103}$ & $\frac{98}{60}$ & $\frac{83}{44}$ & $\frac{1622}{1350}$ & 83,2 \\
\hline
\end{tabular}

S o u r c e: Own calculation. 
The largest Rendzinas area is found in Volyn' region, which is $415 \mathrm{~km}^{2}$ or $40,7 \%$ of the total regional Rendzinas area, $359 \mathrm{~km}^{2}$ of which are arable lands or $44,3 \%$ of the total arable Rendzinas area (tab. 1). Rendzic Leptosols are mostly allocated on the elevated relief elements, where quaternary deposits covering eluvium-diluvium chalks are washed out. The given soils are found as separate lots among Podzolic soils (Albic Retisols Arenic). Depending on bedding conditions, Rendzinas differ by the profile structure, texture composition and other properties. On the chalk hills and slopes, they are characterized by ground stone humus horizon. Ground stone consists of parent rock, sometimes with a substantial admixture of flint. Solid chalk or cretaceous marl plate lies on the depth of $35-50 \mathrm{~cm}$. On the upland lots of watersheds, Rendzinas have somewhat more powerful upper humus horizon $(25-30 \mathrm{~cm})$, and the depth of solid chalk plate is $50-70 \mathrm{~cm}$. Within the inter-watershed lowlands, Rendzinas profile capacity can reach $1 \mathrm{~m}$ and its underneath is usually clayish.

Concerning Rendzinas area, Rivne and L'viv regions take the second and the third place $-231 \mathrm{~km}^{2}$ (of which arable lands are 23,3\%) and $227 \mathrm{~km}^{2}$ (of which arable lands are $23,7 \%$ ) (Tab.1). They are formed in conditions of plain-hill relief on eluvium-diluvium crust of cretaceous marl weathering, under woody and grassy vegetation, in water regime washing type. Most widespread are deep humus type Rendzinas with a chernozem profile structure. The allocation of these soils on the upper interfluve lots causes genetic profile formation without any traces of claying.

In Ternopol', Khmelnitsky and Chernivtsi regions Rendzinas areas make 27, 36 and $83 \mathrm{~km}^{2}$, correspondingly. A distinctive feature of Rendzinas massive areas in Ternopol' region is that they are close to limestone hills of Malyi Polisya, where less thickness is washed off and the products of limestone and cretaceous marl weathering, which become soil parent rocks, appear on the surface (Tab. 1). In Khmelnitsky, region continuous Rendzinas areas lie on the steep and declivous river sloping, where eluvium of cretaceous marl and Upper Baden limestone is the soil parent rock. The characteristic feature of continuous Rendzinas areas in Chernivtsi region is that they are disposed in a narrow stripe form along the Dniester valley, on steep slopes of different exposition.

The investigation of geographic regularities of Rendzinas distribution, their composition and property change under intensification of agricultural production, which led to acceleration of soil degradation processes, is an urgent problem allowing the elaboration of modern adaptive nature-oriented and environmentally friendly systems and methods of land management, which are of vital importance during the present agrarian reform.

Therefore, the Western region of Ukraine in agricultural terms has been developed for a long time. In the structure of agricultural land, predominate arable land. Rendzic Leptosols tilled to $-79,5 \%$.

In order to determine the nature and direction of changes in the morphogenetic properties of developed Rendzinas under the influence of modern agrogenic transformation processes, we carried out comparative analysis of the values of molar ratios, Leach factor $(\beta)$, constitutional water content, and the magnitude of the change in the silicate part of the soil, which were calculated from the data of different research periods [9]. 
Comparison of the morphometric indices of full-profile Rendzinas for more than fifty years of their intensive use as arable land for the cultivation of grain, leguminous and technical crops shows that: 1) increased humus capacity-accumulative agroheterogeneous, residual carbonate horizon on average $4-5 \mathrm{~cm}$; 2 ) the thickness of the transient humus horizon decreases as a result of the stacking of its upper part; 3 ) changes in the nature of transitions between genetic horizons; they are better expressed by color, density, as well as by the content and size of residual eluvial-skeletal material; 6) in general, the density of the structure in all horizons of the profile has increased, while the maximum seal is observed in the region of the sublingual sole (the equilibrium density of the structure is $1,63 \mathrm{~g} / \mathrm{cm}^{3}$ ).

Under the influence of intensive agriculture, changes occurred in the structural organization of the entire genetic profile, which was reflected in the stretchedness of the humus profile of full-profile Rendzic Leptosols $(\approx 5-6 \mathrm{~cm})$, the downward movement of the profile of humus substances (due to pedo-turbational vertical cracking) and, as a result, the formation of a more powerful transitional humus horizon and the presence of profile differentiation for the residual carbonate neoplasms.

The agronomic transformation of the studied Rendzinas along with the changes in the morphological structure was also reflected in the magnitude of molar ratios and leach factors ( $\beta$ ) calculated from the data of different study periods (Tab. 2).

Table 2

Changes of Rendzic Leptosols Properties under Intensive Agriculture

In Western Region of Ukraine

Зміни властивостей рендзин Західного регіону України в умовах інтенсивного землеробства

\begin{tabular}{|c|c|c|c|c|c|c|c|c|}
\hline \multirow{3}{*}{$\begin{array}{l}\text { Index } \\
\text { Depth, cm }\end{array}$} & \multicolumn{4}{|c|}{ Rivne and L'viv regions } & \multicolumn{4}{|c|}{ Volyn' region } \\
\hline & \multicolumn{2}{|c|}{ 1949-1950 years } & \multicolumn{2}{|c|}{ 1995-2013 years } & \multicolumn{2}{|c|}{ 1949-1950 years } & \multicolumn{2}{|c|}{ 1995-2013 years } \\
\hline & $0-20$ & $20-40$ & $0-20$ & $20-40$ & $0-20$ & $20-40$ & $0-20$ & $20-40$ \\
\hline Organic matter, $\%$ & 4,32 & 2,71 & 3,26 & 2,18 & 6,60 & 3,77 & 4,80 & 3,55 \\
\hline $\mathrm{C}_{\mathrm{HA}} / \mathrm{C}_{\mathrm{FA}}$ & \multicolumn{2}{|c|}{-} & \multicolumn{2}{|c|}{$1,3-1,4$} & \multicolumn{2}{|c|}{ - } & \multicolumn{2}{|c|}{$1,01-1,08$} \\
\hline Content $\mathrm{CaCO}_{3}, \%$ & 15,6 & 25,3 & 12,4 & 19,9 & 26,7 & 35,9 & 23,1 & 30,2 \\
\hline $\begin{array}{l}\text { Profile differentiation factor } \\
\text { (Sca) by content } \\
\mathrm{CaCO}_{3}(\mathrm{~A} / \mathrm{Cca} / \mathrm{Ahca})\end{array}$ & \multicolumn{2}{|c|}{2,93} & \multicolumn{2}{|c|}{2,67} & \multicolumn{2}{|c|}{2,38} & \multicolumn{2}{|c|}{2,33} \\
\hline $\begin{array}{l}\text { Molar Ratio } \\
\mathrm{CaO}+\mathrm{MgO} / \mathrm{Al}_{2} \mathrm{O}_{3}\end{array}$ & - & - & 4,20 & 11,7 & 3,23 & 8,07 & 8,89 & 16,18 \\
\hline Leach Factor $(\beta)$ & - & - & 0,17 & 0,35 & 0,21 & 0,53 & 0,16 & 0,29 \\
\hline Constitutional water, $\%$ & - & - & 4,61 & 4,65 & 7,56 & 8,35 & 4,56 & 5,22 \\
\hline Molar quantity, $\mathrm{H}_{2} \mathrm{O}$ & - & - & 256 & 258 & 420 & 464 & 253 & 290 \\
\hline $\begin{array}{l}\text { Change coefficient of the } \\
\text { silicate part }\end{array}$ & - & - & 1,05 & 1,06 & 0,70 & 0,77 & 0,98 & 1,12 \\
\hline
\end{tabular}

S o u r c e: Own calculation. 
This is manifested in the expansion of the parameters of the molar ratio, in fact, within the entire small-lobe part of the profile of the investigated soils. The content of constitutional water in the mineral profile of the investigated soils changes somewhat in the upper and, especially, in the middle part. The coefficient of change of the silicate part in the humus and accumulative horizon of full-profile Rendzinas is from 0,98 to 1,05. At the same time, its value increases in the transition horizon (Tab. 2).

In general, the processes of intrinsic weathering in the mineral profile of Rendzinas area are low in intensity and are manifested only in the upper and, especially, in the middle parts of the genetic profile. This is confirmed by the conclusions made by us regarding the compliance of the full-range Rendzic Leptosols in Western region of Ukraine with the permanent stage of their ontogenetic development.

Rendzic Leptosols reclamation and their long-term intensive use as arable lands lead to agro degradation lying in humus content decrease (dehumification), considerable disturbance of nutritive balance (depletion), internal soil weathering intensification and decarbonation (chemical degradation), considerable deterioration of water-air regime, over-condensation and disaggregation (physical degradation), erosive outwash of upper humus horizons (profile degradation).

Rational use of Rendzinas in case of their development is possible in the event of the creation of favorable conditions for humus formation and humus copying and further optimization of the humus state due to increased content and stocks of organic matter. An effective measure to create such conditions is the introduction of fertilizers. The most effective niche system of soil fertilization is organo-mineral, which primarily provides agricultural crops with the necessary and affordable nutritional elements and contributes to the accumulation of humus.

The introduction of grass-legume crop increases the content of organic matter in the soil, but it is effective only in conditions of high agricultural technology. To improve and maintain the effective fertility of Rendzinas, it is extremely important to improve the water regime by organizing them. This is possible subject to the introduction of grass-legume rotation, the components of which should be sowing a mixture of perennial legumes and grass. Among the beans, the esparcet deserves special attention, since this plant is best adapted to excessive amounts of carbonates in the soil. Thus, raising a mixture of perennial bean and cereal grasses contributes to the improvement of Rendzinas structure, and stabilization of their water-air regime.

Therefore, the article analyzes the theoretical and methodological principles of the process-genetic approach to the study of ontogenesis and soil geography at the regional level. The new methodological approach in geographic and genetic research of ontogenesis and geography of Rendzic Leptosols is considered on the basis of introduction of simulation methods, of soil chronological series and balance of substances. The features of the Rendzinas ontogenesis have been shown in natural and natural-man-made landscapes with different biolithogenic conditions of soil formation. We propose to call the primary stage, an initial stage $\rightarrow$ stage of development - a perfect stage (stage of improvement) $\rightarrow$ stage of equilibrium functioning or climax - a permanent stage (stable, sustainable) $\rightarrow$ and additionally highlighted 
evolutionary stage (qualitative irreversible changes of the invariant). The characteristic features of the agricultural transformation of Rendzic Leptosols are shown and scientifically grounded approaches of optimization of use and protection of investigated soils are offered.

\section{REFERENCES}

1. Abakumov, E. V., \& Shelemina, A. N. (2000). Pochvy sten Koporskoy kreposti. 3. Moskva: Pochv. in-t. im. V. V. Dokuchaeva RASHN. 1-3 (in Russian).

2. Dushufor, F. (1968). Fundamentals of Soil Science. Evolution of soil (experiment to study the dynamics of soil formation). Paris. 502-511.

3. Guidelines for soil description, 4th edition (2006). Food and Agriculture Organization of the United Nations. Rome.

4. IUSS Working Group WRB (2007). World Reference Base for Soil Resources 2006, first update. World Soil Resources Reports, 103. FAO. Rome.

5. Kovda, V. A. (1973). Osnovy uchenia o pochvah, 2. Obch. teor. pochvoobraz. protsessa. Moskva: Nauka. 468 pp. (in Russian).

6. Kyrylchuk, A. (2014). Geography of Rendzinas in Western region of Ukraine. Izvestiya Akademii nauk Moldovyi. Nauki o zhizni, 1 (322), 175-182.

7. Kyrylchuk, A. A., \& Poznyak, S. P. (2004). Dernovo-karbonatni grunty (Rendziny) Male Polissja, Lviv: Vyd. centr, Lviv. Nacional. Univer. im. Ivana Franka. 114-124 (in Ukrainian).

8. Kyrylchuk, A., \& Poznyak, S. (2010). Transformation processes in mineral part of Rendzinas of Malyi Polissya. Zeszyty naukowe. Rzeszow, 13, 133-136.

9. Kyrylchuk, A., \& Poznyak, S. (2013). Pedogenic process on eluvium-diluvium solid carbonate rocks. Polish journal of Soil Science. Vol. XLVI, 2, 131-138.

10. Kyrylchuk, A. (2013). Contemporary transformation processes of Rendzinas mineral profi le in Western region of Ukraine. Romania journal of Soil Science. Vol. XLVII. 1, 15-28.

11. Kyrylchuk, A. (2013). Peculiarities of Rendzic Leptosols distribution in Western region of Ukraine. Geography. Vilnius. T. 49. 2. pp. 105-113.

12. Kyrylchuk, A. (2015). Morphogenesis of carbonatious Rendzinas profi le of the Western Ukrainian region on different stages of their ontogenesis. Scientifi c Papers Series "Management, Economic Engineering in Agriculture and Rural Development" Bucharest. Vol. 15, 4. 131-138.

13. Kyrylchuk, A. (2017). Geographic and Bio-lithogenic Features of Genesis and Dissemination of Rendzinas in the Western Ukrainian Region. Scientifi c Papers Series "Management, Economic Engineering in Agriculture and Rural Development" Bucharest. Vol. 17, 1. 265-272.

14. Liseckij, F. N. (2008). Agrogennaja transformacija počv suhostepnoj zony pod vlijaniem antičnogo i sovremennogo ètapov zemlepol'zovanija. Počvovedenie, 8, 1-16 (in Russian).

15. Pozniak, S., \& Tryhub, V. (2009). Professor Ivan Gogolev=Professor Ivan Gogolev. Lviv: Vyd. tsentr LNU im. Ivana Franka (in Ukrainian).

16. Rode, A. A. (1984). Genezys pochv i sovremennye protcesy pochvoobrazovaniya. Soil Genesis and modern processes of soil formation, Moscow : Nauka. 92 pp. (in Russian).

17. Vernander, N. B. (1986). Pochvy lesostepnoj zony. Pryroda Ukrainskoj SSR. Počvy. Kyiv: Naukova dumka, 82-92 (in Russian). 


\section{СПИСОК ВИКОРИСТАНОЇ ЛІТЕРАТУРИ}

1. Абакумов E. В., Шелемина А. Н. Почвы стен Копорской крепости // Тезисы докладов III съезда Докучаевского общества почвоведов. Москва. Почвенный институт им. В.В. Докучаева РАСХН, 2000. Кн. 3. С. 3.

2. Dushufor F. Fundamentals of Soil Science. Evolution of soil (experiment to study the dynamics of soil formation). Paris, 1968. P. 502-511.

3. Guidelines for soil description, 4th edition, Food and Agriculture Organization of the United Nations, Rome. 2006.

4. IUSS Working Group WRB. World Reference Base for Soil Resources 2006, first update 2007. World Soil Resources Reports No. 103. FAO, Rome. 2007.

5. Ковда B. A. Основы учения о почвах. Общая теория почвообразовательного процесса. Москва: Наука, 1973. Кн. 2. 468 с.

6. Kyrylchuk A. Geography of Rendzinas in Western region of Ukraine. Izvestiya Akademii nauk Moldovyi. Nauki o zhizni, 2014. № 1 (322). P. 175-182.

7. Кирильчук А. А., Позняк С. П. Дерново-карбонатні грунти (рендзини) Малого Полісся. Львів : Вид. центр ЛНУ ім. Івана Франка, 2004. 180 с.

8. Kyrylchuk A., Poznyak S. Transformation processes in mineral part of Rendzinas of Malyi Polissya. Zeszyty naukowe. Rzeszow, 2010. No 13. P. 133-136.

9. Kyrylchuk A., Poznyak S. Pedogenic process on eluvium-diluvium solid carbonate rocks. Polish journal of Soil Science. 2013. Vol. XLVI. No. 2. P. 131-138.

10. Kyrylchuk $A$. Contemporary transformation processes of Rendzinas mineral profile in Western region of Ukraine. Romania journal of Soil Science. 2013. Vol. XLVII. No. 1. P. 15-28.

11. Kyrylchuk A. Peculiarities of Rendzic Leptosols distribution in Western region of Ukraine. Geography. Vilnius, 2013. T. 49. No 2. P. 105-113.

12. Kyrylchuk A. Morphogenesis of carbonations Rendzinas profile of the Western Ukrainian region on different stages of their ontogenesis. Scientific Papers Series "Management, Economic Engineering in Agriculture and Rural Development”. Bucharest, 2015. Vol. 15. Issue 4. P. 131-138.

13. Kyrylchuk A. Geographic and Bio-lithogenic Features of Genesis and Dissemination of Rendzinas in the Western Ukrainian Region. Scientific Papers Series "Management, Economic Engineering in Agriculture and Rural Development”. Bucharest, 2017. Vol. 17. Issue 1. P. 265-272.

14. Лисецкий Ф. Н. Агрогенная трансформация почв сухостепной зоны под влиянием античного и современного этапов землепользования // Почвоведение. 2008. № 8. C. $1-16$.

15. Професор Іван Гоголєв = Proffessor Ivan Gogolev / Упоряд. С. Позняк, В. Тригуб / за ред. С. Позняка. Львів : Вид. центр ЛНУ ім. Івана Франка, 2009. 586 с.

16. Роде A. А. Генезис почв и современные процессы почвообразования. Москва : Наука, 1984. C. 137-146.

17. Вернандер Н. Б. Почвы лесостепной зоны // Природа Украинской ССР. Почвы. Киев : Наукова думка, 1986. С. 82-92. 


\title{
ОСОБЛИВОСТІ ОНТОГЕНЕЗУ І ГЕОГРАФІЇ РЕНДЗИН (RENDZIC LEPTOSOLS) ЗАХІДНОГО РЕГІОНУ УКРАЇНИ
}

\author{
Андрій Кирильчук \\ Львівський національний університет імені Івана Франка, \\ вул. П. Дорошенка, 41, 79007, Львів, Украӥна, \\ e-mail: andriy.kyrylchuk@lnu.edu.ua
}

Обгрунтовано теоретико-методологічні засади процесно-генетичного підходу до вивчення онтогенезу і географії грунтів на регіональному рівні. Удосконалено методику географогенетичного дослідження онтогенезу і географії рендзин завдяки впровадженню методів моделювання, грунтових хронорядів, балансу речовин та енергетичної оцінки потенціалу грунтотворення. Встановлено особливості онтогенезу рендзин у природних і природноантропогенних ландшафтах з різними біолітогенними умовами грунтотворення. За результатами виконаних досліджень складено картосхему географії рендзин Західного регіону України. Обгрунтовано підходи до виділення таких стадій онтогенезу рендзин, як: ініціальна (початкова) $\rightarrow$ перфектна (стадія розвитку й удосконалення) $\rightarrow$ перманентна (стадія зрілості, стабільності) $\rightarrow$ еволюційна (стадія саморозвитку та якісних змін). Проаналізовано енергетичні та термодинамічні властивості хронорядів грунтотворних порід і рендзин Західного регіону України на різних стадіях ïx онтогенезу. Визначено параметри та величини показників у рендзинах, які відображають характер і напрям розвитку елементарних грунтових процесів, а також особливості формування їхніх морфогенетичних властивостей. Встановлено характерні ознаки агрогенної трансформації рендзин і запропоновано науково обгрунтовані підходи оптимізації використання та охорони досліджуваних грунтів.

Ключові слова: онтогенез і географія рендзин, елементарні грунтові процеси, стадіальність онтогенезу, агрогенна трансформація. 